\title{
Scotland and Brexit: the state of the Union and the union state
}

\author{
Christopher McCorkindale, University of Strathclyde
}

\section{Introduction}

The constitution of the United Kingdom has always had something of a Jekyll and Hyde nature: an internal and uneasy tension between its unitary and union state identities. JDB Mitchell's famous assertion that the Union parliament was 'born unfree' ${ }^{1}$ might be contested, but it reminds us that from its very inception the ability of the unitary state to hoard political power at the centre - to sustain the claim that the legitimacy and authority of all other institutions flows from, through and back to $^{2}$ the sovereign Crown-in-Parliament - has depended upon the persuasion that a layer of constitutional protection exists in order to preserve the distinct civil, political and cultural identities of its constituent nations against the abuse of that power. Where the constituent nations are no longer so persuaded there the unitary state is confronted with a dilemma: to adapt or to fail.

As a result of the 2016 EU Referendum the capacity of the UK constitution to straddle its unitary and union state identities is under strain. On the one hand, that the wish of the Scottish (as well as that of the Northern Irish) majority to remain in the EU was rendered impotent against the nationwide majority who voted to leave has caused some to reflect on a persistent democratic deficit at the centre. ${ }^{3}$ On the other hand, the way in which a political right with no mainstream counterpart in Scottish politics have taken control (though I use this term loosely!) of Brexit- aided and abetted by the disavowal of any responsibility on the political left either convincingly to make the case for remain or to present a compelling alternative vision of what it means to leave - has reopened the case for greater autonomy, or even independence, in Scotland.

In what follows I will explore three manifestations of this tension between the UK as unitary and the UK as union state that flow directly from the referendum and its surprising result: in section II, the democratic deficit which persists both in the referendum process and in its outcome; in section III, the return of the Scottish independence question; and, in section IV, the call for further devolution from the centre as a response to Brexit.

\section{The Union under strain}

It wasn't supposed to be this way. David Cameron's three-pronged strategy - predicated on a successful campaign to remain in the EU - was to call an EU referendum in order to resolve crises internal to the Conservative Party. First, he hoped that by calling a referendum he would stave off the threat of UKIP in the 2015 General Election. Secondly, he hoped to satisfy - and in winning the referendum even to contain - the Euroscpetics in his party behind (and to the right of) him. Thirdly, he hoped that the prospect of a vote to leave the EU would spook his European counterparts into

\footnotetext{
1 JDB Mitchell, Constitutional Law (4 ${ }^{\text {th }}$ edn) (W Green 1964) ch 4.

${ }^{2}$ Nowhere more salient than in the various returns to Direct Rule in Northern Ireland.

${ }^{3}$ A point made by the First Minister, Nicola Sturgeon, when launching the Scottish Government's consultation on a Draft Referendum Bill (N Sturgeon, 'Foreword' in the Scottish Government's Consultation on a Draft Referendum Bill (2016) 1). Contrast the nationwide result - Leave $51.9 \%$; Remain $48.1 \%$ - with the Scottish votes: Leave $38 \%$; Remain $62 \%$.
} 
making meaningful concessions in his attempts to renegotiate the terms of the UK's continued membership. ${ }^{4}$ The rest, as they say, is history.

Perhaps the most significant consequence of this failed strategy has been that - by acting primarily to face down an internal crisis - the Conservative Government neglected to pay sufficient attention to the implications that an unexpected defeat might have outwards, across the union. This omission, and its potentially disastrous effects, have been brought into sharp relief in Northern Ireland where the loaded question of a hard border across the island (and thus between the EU and the UK) has been thrust onto the political agenda. But with regard to Scotland too the Conservative and Unionist Party has shown itself to be ignorant to the substantive (for example, the overlap of areas within EU and devolved competences) and to the procedural (the possible need to re-open Scotland Act) effects of Brexit. Little wonder that - as those effects have revealed themselves - the UK Government's rhetoric has hardened. When she became Prime Minister, Theresa May very intentionally put the union at the front and centre of her agenda. "The word "unionist" is very important to me,' she told the assembled media following her appointment with the Queen, as she stressed the 'precious, precious bond between England, Scotland, Wales and Northern Ireland. ${ }^{5}$ As if to emphasise this, her first official visit as PM was to Edinburgh where, following a meeting with the First Minister, she said that the Scottish Government would be 'fully engaged in our discussion [with the EU],' and that article 50 would not be triggered 'until...we have a UK approach and objectives for negotiations. ${ }^{\prime 6}$

Since then, however, a far more centrist approach has been adopted. As Mark Elliott has said, the very clear message delivered at the Conservative Party conference was that Brexit will be 'an executive-led withdrawal process, [intolerant of] interference in that process by either Parliament or the devolved institutions'; Nicola Sturgeon has had cause to express her disappointment that the Scottish Government has largely been kept out of the loop with regard to the formulation of a UK negotiating position; ${ }^{8}$ meanwhile, at the UK level the Secretary of State for Scotland (as well as his Northern Irish and Welsh counterparts) have not been made part of the cabinet's Brexit subcommittee and will instead attend 'as required' by the Prime Minister. ${ }^{9}$ Not only will Scotland be

\footnotetext{
${ }^{4}$ On which see J Murkens, 'David Cameron's tactics may take the UK out of the EU, and Scotland out of the UK' British Politics and Policy blog (13 November 2015) < http://blogs.lse.ac.uk/politicsandpolicy/david-cameronstactics-may-take-the-uk-out-of-the-eu-and-scotland-out-of-the-uk/>.

5 'Statement from the new Prime Minister Theresa May' (13 July 2016)

<https://www.gov.uk/government/speeches/statement-from-the-new-prime-minister-theresa-may>.

6 'Brexit: PM is "willing to listen to options" on Scotland' BBC News (15 July 2016)

<http://www.bbc.co.uk/news/uk-scotland-scotland-politics-36800536>.

${ }^{7}$ M Elliott, 'Theresa May's “Great Repeal Bill”: Some preliminary thoughts' (5 October 2016) Public Law for

Everyone blog <https://publiclawforeveryone.com/2016/10/02/theresa-mays-great-repeal-bill-somepreliminary-thoughts/>.

${ }^{8}$ S McNab, 'Sturgeon: May in not "honouring her promise" to Scotland on talks' The Scotsman (17 October 2016) <http://www.scotsman.com/news/politics/sturgeon-may-is-not-honouring-her-promise-to-scotland-ontalks-1-4260095>. These frustrations were not eased by the first high level meeting between the Prime Minister and her Welsh, Northern Irish and Scottish counterparts at Downing Street: P Waker, 'Sturgeon says Brexit meeting was "deeply frustrating"' The Guardian (24 October 2016)

<https://www.theguardian.com/politics/2016/oct/24/nicola-sturgeon-says-brexit-meeting-was-deeplyfrustrating $>$.

${ }^{9}$ T Peterkin, 'Theresa May leaves out Scottish Secretary from Brexit cabinet' The Scotsman (14 October 2016) < http://www.scotsman.com/news/politics/sturgeon-may-is-not-honouring-her-promise-to-scotland-on-talks-14260095>.
} 
taken out of the EU against its will - and the Prime Minister has been clear that for Scotland too Brexit means Brexit ${ }^{10}$ - but the process and the shape of Brexit will be determined by a Conservative Party with just one Scottish MP (of 59) and by a UK Government that feels comfortable to exclude both the Scottish Government and its own Secretary of State for Scotland from the room. Not since Poll Tax has the democratic deficit at the heart of this 'precious, precious' union of nations been so clearly exposed.

During the passage of the EU Referendum Bill an SNP amendment sought to pre-empt the precariousness of this position with the introduction of a 'double-majority' lock: a requirement whereby any UK wide vote to leave the EU would only be given effect in the (highly unlikely) event that it was matched by majorities for 'leave' in each of the union's constituent nations. This was an explicit pitch to the UK's union state identity. As Alex Salmond told the House of Commons, in response to the objection that one state might thereby hold the rest of the UK to ransom:

Nations within a multi-national state should be recognised as more than regions, counties or areas and should not be counted by population; they are national entities in their own right, and that confers a relationship of respect. ${ }^{11}$

Whilst the Welsh First Minister, Carwyn Jones, resisted this particular mechanism, the broader union state narrative was reaffirmed by his joint communique with Nicola Sturgeon which warned the UK Government that it would be 'unacceptable' for the UK to leave the EU against the wishes of the people in Scotland or in Wales. ${ }^{12}$ The amendment was never likely to succeed: the trend in UK referendums has been to reach decisions on the basis of a nationwide simple majority, and the perception that such mechanisms would have been instrumental to a preferred outcome strongly militated against their use. ${ }^{13}$ As such the response of the UK Government when rejecting the amendment - that ' $[\mathrm{w}] \mathrm{e}$ are one United Kingdom, [and that] there will be one referendum...that will be decided on a majority of those who vote' ${ }^{14}$ - was unsurprising and constitutionally justifiable. Nevertheless, the strong assertion by the Scottish Government (and by the SNP group in Westminster) that a 'double-majority' was necessary in order to protect Scotland's interests should be seen as more than mere political grand-standing in pursuit of a lost cause: it spoke to the need for new constitutional apparatus in order to take seriously the post-independence referendum commitment to a new and more responsive Union.

These are tensions which have resurfaced in the aftermath of the referendum result. The Scottish Government has adopted the view that legislation which seeks to remove the EU law boundary from the Scotland Act, or - as in the case of the Great Repeal Bill - which seeks to place all EU law

\footnotetext{
${ }^{10} \mathrm{~S} J o h n s o n$, 'Theresa May: No Scotland opt-out or veto from Brexit' The Telegraph (2 October 2016) <http://www.telegraph.co.uk/news/2016/10/02/theresa-may-no-scotland-opt-out-or-veto-from-brexit/>. ${ }^{11}$ HC Deb 16 June 2015, vol 597, cols 192-193.

${ }^{12} \mathrm{M}$ Gardham, 'Sturgeon and Welsh First Minister Carwyn Jones in joint call over EU vote' The Herald (3 June 2015) $<$ http://www.heraldscotland.com/news/13411315.Sturgeon and Welsh First Minister Carwyn Jones in joi nt call over EU vote/>.

${ }^{13}$ Tainted, no doubt, by the Labour MP George Cunningham's cynical addition to the 1979 Scottish Devolution Referendum of a special majority requirement in order to frustrate devolution from taking hold.

14 'Cameron rejects Sturgeon Euro veto move' The Herald (29 October 2014) $<$ http://www.heraldscotland.com/news/13186937.Cameron rejects Sturgeon s Euro veto move/>.
} 
(including EU law in areas that are in principle devolved) on a statutory footing pending later amendment, replacement or repeal, will require the UK Government to seek a legislative consent motion (LCM) at Holyrood. There are two important points to be made in relation to this position. First, an argument can be (and has been) made that the Sewel Convention - by which consent will 'normally' be sought from the Scottish Parliament where the UK Parliament wishes to make primary legislation either in a devolved policy area or to increase or decrease devolved competence ${ }^{15}-$ is not engaged here since the circumstances are not 'normal' within the meaning of the convention. ${ }^{16}$ Such arguments should be resisted. In order for the UK to carry the support of its constituent nations through Brexit it is essential that the democratic deficit at the centre which has plagued the result and its aftermath can now be recovered. Engaging the devolved institutions in the process of legislative consent is one meaningful way in which that can begin to happen. Secondly, and as Alan Page has said, should UK Ministers be given the power to amend, replace or repeal EU law by way of subordinate legislation the absence of any requirement for the Scottish Parliament to be informed of, let alone to consent to, the making of such legislation would leave a 'significant potential gap in the framework of Scottish parliamentary control over UK law making in devolved areas, which the Scottish Parliament should be alert to the need to close. ${ }^{17}$ During the passage of the Scotland Bill in 2012 the Scottish Parliament was able constructively to refuse an LCM in order to encourage the UK Government to return to seek consent for an amended Bill on terms more palatable to the devolved legislature. ${ }^{18}$ Whilst it is extremely unlikely that this new dynamic of qualified consent/dissent will wring from the UK Government concessions on heavy substantive issues such as Scotland's access to the single market, on important procedural issues such as Holyrood's supervision of UK subordinate legislation in devolved areas the LCM procedure might provide a useful mechanism by which the devolved institutions can insert themselves into and affect the process of leaving the EU.

\section{The means to an end}

During the EU referendum campaign it was a common (albeit contested) ${ }^{19}$ refrain that should Scotland be taken out of EU against its will this would lead inevitably to the dissolution of the union. The rise in support for independence during the 2014 Independence Referendum campaign (from approximately $24 \%$ when the SNP was elected to the Scottish Parliament with a historic majority in 2011 to the $45 \%$ who voted 'yes' in the referendum itself) as well as the demographics underlying

\footnotetext{
${ }^{15}$ As set out in Devolution Guidance Note 10 <http://www.gov.scot/Resource/Doc/37349/0066833.pdf>.

${ }^{16}$ House of Lords Constitution Committee, The invoking of Article 50 (4 $4^{\text {th }}$ report 2016/17) para 35.

${ }^{17}$ A Page, 'The implications of EU withdrawal for the devolution settlement' for the Culture, Tourism, Europe and External Relations Committee (4 October 2016) para 13.

${ }^{18}$ C McCorkindale, 'Echo Chamber: the 2015 General Election at Holyrood - a word on Sewel' Scottish Constitutional Futures Forum blog (13 May 2015)

$<$ http://www.scottishconstitutionalfutures.org/OpinionandAnalysis/ViewBlogPost/tabid/1767/articleType/Arti cleView/articleld/5594/Chris-McCorkindale-Echo-Chamber-the-2015-General-Election-at-Holyrood-a-word-onSewel.aspx>.

${ }^{19}$ Prior to the referendum it was suggested by Michael Keating and Malcolm Harvey that the most likely driver for significant constitutional change would be a result which saw a (narrow) English and Welsh majority vote to leave undone by a significant majority for remain in Scotland, in which case the English might willingly let Scotland go! See proceedings of the Royal Society of Edinburgh's event 'The UK in Europe. In or Out?' (31 May 2016) <https://www.royalsoced.org.uk/cms/files/events/reports/2016/The-UK-in-Europe In-or-

Out Inverness.pdf>.
} 
that support, ${ }^{20}$ has kept the question alive, at least in the short-medium term. Furthermore, since the referendum in 2014 pro-independence majorities have for the first time been returned by the Scottish electorate both to Westminster (where, in 2015, the SNP took 56 of 59 available Scottish seats, with 50\% of the vote) and to Holyrood (where, in 2016, the SNP (63 seats) and Greens (6 seats) combine to give a pro-independence majority of 4). Even if, as appeared to be the case at Holyrood in 2011, ${ }^{21}$ the complexion of these chambers reflects the perceived competence of the SNP as a party of government (at Holyrood) and opposition (at Westminster) within the union the fact of these dual majorities is a further reminder that in its present condition the union remains unstable: the unitary state vulnerable to discontent in its northern territory.

This vulnerability, such as it is, stands in stark contrast to the relative calm which bridged the independence and EU referendums. At that point the Scottish question appeared to have been put on the back burner. So, the SNP's manifesto for the 2015 General Election reaffirmed the party's support for independence, but stressed that 'this election...is about making Scotland stronger': making use of Scottish votes at Westminster to ensure that the Smith Commission's promise of further devolution is implemented in full. ${ }^{22}$ Meanwhile, the party's manifesto for the 2016 Holyrood elections asserted the Scottish Parliament's 'right' (though falling short of an explicit promise to exercise that right) to hold a referendum, but with an important qualification: if there is 'clear and sustained evidence that independence has become the preferred option of a majority of the Scottish people'23 (as evidence by 'range of polls over a period of time') ${ }^{24}$ or if there is 'a significant and material change in circumstances that prevailed in 2014', citing as an example Scotland being taken out of the EU against its will. ${ }^{25}$ The second qualification has of course now been satisfied, and whilst the referendum outcome has not (at the time of writing) had a significant impact on support for independence ${ }^{26}$ the SNP took the decision to include a Draft Referendum Bill in their programme for government. That bill has now been published for consultation. However, there remain significant political and constitutional hurdles to cross before such a bill can become law.

As a minority government the implementation by the SNP of any referendum commitment will require support from elsewhere in the chamber. On this question the manifesto of their only natural ally - the Scottish Greens - was more ambiguous, making no explicit promise to campaign for a second referendum but committing themselves to campaign for independence should such a referendum take place. ${ }^{27}$ This hurdle has been somewhat lowered by the Greens' subsequent commitment to vote with the SNP should they decide to introduce a Referendum Bill, and to do so

\footnotetext{
${ }^{20} \mathrm{~J}$ Curtice, 'So Who Voted Yes and Who Voted No?' What Scotland Thinks (26 September 2014) < http://blog.whatscotlandthinks.org/2014/09/voted-yes-voted/>.

${ }^{21}$ C McCorkindale, 'An Accidental Referendum' Scottish Constitutional Futures blog (16 August 2016) $<$ http://www.scottishconstitutionalfutures.org/OpinionandAnalysis/ViewBlogPost/tabid/1767/articleType/Arti cleView/articleld/2040/Christopher-McCorkindale-An-Accidental-Referendum.aspx>.

22 Scottish National Party manifesto, Stronger for Scotland (2015) 35.

${ }^{23}$ Scottish National Party manifesto, Re-elect Nicola Sturgeon (2016) 23.

${ }^{24} \mathrm{G}$ McPherson, "Nicola Sturgeon says "range of polls" showing independence support is trigger for referendum re-run' The Courier (2 May 2016) <https://www.thecourier.co.uk/fp/news/politics/scottishpolitics/165004/nicola-sturgeon/>.

${ }^{25}$ SNP 2016 manifesto (n 23) 23.

${ }^{26} \mathrm{~J}$ Curtice, 'How Brexit Has - and Has Not - Made a Difference' What Scotland Thinks (18 September 2016) <http://blog.whatscotlandthinks.org/2016/09/how-brexit-has-and-has-not-made-a-difference/>.

${ }^{27}$ Scottish Greens manifesto, Scotland Can (2016) <https://greens.scot/scotland-can>.
} 
without using their votes to win concessions in other policy areas. ${ }^{28}$ By way of contrast, it has been reported that the Prime Minister would strongly consider blocking ${ }^{29}$ or delaying ${ }^{30}$ any second independence referendum proposed by the Scottish Government in the wake of Brexit, and the response of Number 10 to the consultation exercise has been to deny that there is a mandate for one to be held. ${ }^{31}$ Given the principled considerations (that the Greens' position implies support for a second independence referendum in the lifetime of the Parliament, and therefore that there is a parliamentary mandate for one to be called) as well as the pragmatic considerations (the risk that a veto or the manipulation of the referendum might further the nationalist cause) ${ }^{32}$ in play, this is a position that might well prove to be untenable.

Of course, a political mandate to act does not necessarily align with the legal power to do so. Regardless of the mandate doctrine, any Referendum Act 'is not law' to the extent that inter alia it 'relates to' a reserved matter ${ }^{33}$ (here 'the Union of the Kingdoms of Scotland and England.') ) $^{34}$ Whether legislation 'relates to' a reserved matter is to be assessed 'by reference to the purpose of the provision, having regard (among other things) to its effect in all the circumstances. ${ }^{35}$ For the Scottish Government - who notably did not qualify the right of the Scottish Parliament to legislate with the requirement of a prior transfer of competence from Westminster - a Referendum Bill is already within the parliament's legislative competence because, adopting a narrow reading of the legislation, ${ }^{36}$ its purpose is not to affect the Union but rather to seek (in an advisory referendum) 'the views of people in Scotland on a proposal about the way Scotland is governed' ${ }^{37}$ its legal effect, to enable that referendum to take place. ${ }^{38}$ For the UK Government, the 'purpose and effect' of legislation must be read more broadly than for its direct legal effects, so as to include 'the social or economic purposes which the statute was enacted to achieve. ${ }^{39}$ Given that the First Minister has said she will only call a referendum where a series of polls demonstrate significant support for

\footnotetext{
${ }^{28} \mathrm{~L}$ Kirkaldy, 'Patrick Harvie rules out trying to extract concessions from the SNP in return for backing independence bill' Holyrood Magazine (24 October 2016)

$<$ https://www.holyrood.com/articles/news/exclusive-patrick-harvie-rules-out-trying-extract-concessions-snpreturn-backing>.

${ }^{29}$ A Grice, 'Theresa May rules out second referendum on Scottish independence' The Independent (15 July 2016) <http://www.independent.co.uk/news/uk/politics/brexit-theresa-may-scottish-independencereferendum-rules-out-second-a7139391.html>.

${ }^{30}$ See quotes by Conservative MSP, Adam Tomkins, regarding the use of the section 30 order to delay any referendum, in J Mitchell, 'Sturgeon: Tories plan to stitch up referendum' The Sunday Times (23 October 2016) $<$ http://www.thetimes.co.uk/article/sturgeon-tories-plan-to-stitch-up-referendum-k80rbh6ng>.

${ }^{31}$ 'Scottish Government launches new bill for independence' STV News (20 October 2016) $<$ http://stv.tv/news/politics/1370450-scottish-government-launches-bill-for-second-referendum/>.

${ }^{32}$ S Johnson, 'Ruth Davidson: Next PM should not block Scottish independence referendum' (3 July 2016) < http://www.telegraph.co.uk/news/2016/07/03/ruth-davidson-next-pm-should-not-block-scottishindependence-ref/>.

${ }^{33}$ Scotland Act 1998, s 29(3).

${ }^{34}$ Scotlad Act 1998, sch 5, Pt l, 1(b).

${ }^{35}$ Scotland Act 1998, s 29(3).

${ }^{36}$ Scotland Act 1998, s 101.

${ }^{37}$ Such was the long title of the Draft Bill prepared in advance of the 2014 referendum.

${ }^{38}$ For a more detailed account of this argument see G Anderson et al, 'The Independence Referendum, Legality and the Contested Constitution: Widening the Debate' UK Constitutional Law Association blog (31 January 2012) <https://ukconstitutionallaw.org/2012/01/31/gavin-anderson-et-al-the-independence-referendumlegality-and-the-contested-constitution-widening-the-debate/>.

${ }^{39}$ PW Hogg, Constitutional Law of Canada ( th $^{\text {th }}$ edn) (Thomson Carswell 2007) para 15.5(d). For more detail on the application of s29(3) see A Page, Constitutional Law of Scotland (W Green 2015) 124-128.
} 
independence, those purposes seem clear enough. With such a degree of ambiguity it is inevitable that, if the Scottish Government was to introduce legislation absent a transfer of legislative competence, the matter would make its way to the UK Supreme Court, either by way of a preenactment reference by the UK (and possibly in conjunction with the Scottish) Law Officers, ${ }^{40}$ or by way of a post-enactment challenge raised by a private party.

The legal basis of the 2014 referendum was put beyond doubt by an agreement reached between the Scottish and UK Governments explicitly and temporarily to exclude that poll from the schedule of reserved powers. ${ }^{41}$ This was achieved by way of a transfer of competence by Order-in-Council made under section 30 of the Scotland Act. In light of the uncertain prospects for a Referendum Bill before the Supreme Court it makes sense that the Scottish Government has stated its 'expectation' that an order and agreement would again be sought in advance of a second referendum. ${ }^{42}$ For our purposes, however, the key point is this: that in the Scottish Government's view a section 30 order is (and in 2013 was) a purely pragmatic mechanism (a means of protecting the referendum and its result from judicial review) rather than one arising from constitutional necessity. Notwithstanding the experience of the previous referendum, the constituent nation has reserved for itself the right indeed, in a recent radio interview for Radio 4's Today programme the First Minister has called it her duty - to respond where the unitary state is seen to abuse its power either by harming Scottish interests as a result of the negotiations to leave the EU (citing as 'red lines' membership of the single market and protections for EU citizens and for Scottish workers $)^{43}$ or by seeking to prevent a resulting and politically mandated referendum from taking place at all.

So begins a fascinating dance in which the Scottish Government will use the implicit threat of unilateral legislation in order to force the UK Government from its current trajectory towards a (socalled) 'hard' Brexit. This is high stakes brinkmanship. On the one hand, the UK Government has thus far refused to blink, stating that there will be no opt-out or exceptional status for Scotland with regards either to immigration or to the single market. ${ }^{44}$ On the other hand, by publishing for consultation a draft Referendum Bill the Scottish Government will hope that - as the ill-effects of Brexit begin to manifest - public opinion will tip in favour of independence, all the while daring the UK Government or the UK Supreme Court to block the enabling referendum legislation. Somewhere in the middle lie three more likely options: (1) that a 'softer' approach to Brexit - possibly one which creates for Scotland (and for Northern Ireland) a special status - can be agreed and pursued by the UK and the devolved governments; (2) that where the positions of the respective governments become entrenched the 2014 model can be adopted in order for the UK and devolved governments to put any resulting referendum on a solid legal footing; (3) that political support for independence

\footnotetext{
${ }^{40}$ Scotland Act 1998, s 33.

${ }^{41}$ Agreement between the United Kingdom Government and the Scottish Government and the Scottish Government on a referendum on independence for Scotland (15 October 2012) $<$ http://www.gov.scot/About/Government/concordats/Referendum-on-independence>.

${ }^{42}$ Consultation on a Draft Referendum Bill (n 3 ) 3.

${ }^{43} \mathrm{~T}$ Gordon, 'Nicola Sturgeon to publish plan for Scotland to stay in single market after Brexit' (17 October 2016)

$<$ http://www.heraldscotland.com/politics/14805314.Nicola Sturgeon to publish plan for Scotland to stay in single market after Brexit/?ref=rss $>$.

${ }^{44} \mathrm{~K}$ Schofield, 'Theresa May rejects Nicola Sturgeon's immigration and single market demands' Politics Home (17 October) <https://www.politicshome.com/news/uk/constitution/scottishparliament/news/79921/theresa-may-rejects-nicola-sturgeons-immigration>.
} 
fails to materialise leaving the SNP to lobby the UK Government for further devolution as the UK's EU obligations are unravelled. Wherever the chips fall it is clear that dissensus in and between its constituent parts is driving the transformation of the UK constitution. The imposition of a 'hard' Brexit - or one contrary to Scotland's best interests - will inevitably and severely test the rigidity of the unitary state. In order to survive it is likely that the autonomy of the nations will require to be enhanced further still.

\section{Towards a new Unionism}

An alternative view of Brexit - one that has been put by unionists and nationalists alike - is that far from threatening the union we are instead presented with a unique opportunity to augment devolution beyond the substantial transfer of powers that already flow from the Scotland Acts 2012 and 2016. First, because Scotland's is a 'retaining model' of devolution, the repatriation of power from the EU to the UK ought to begin with the presumption that powers which are exercised at the EU level in subject areas which are in principle devolved - notably in the spheres of agriculture, fisheries and the environment ${ }^{45}$ - will revert to Edinburgh without any requirement to re-open the Scotland Act. Secondly, the freedom of the Scottish Government to act and the Scottish Parliament to legislate in the devolved sphere will be greatly enhanced by the repeal of the EU law boundary to legislative and executive competence. ${ }^{46}$ Thirdly, Brexit might also present opportunities for the devolved institutions to lobby Westminster for yet more powers (for example, the devolution of $V_{A}{ }^{47}$ or of powers to implement a distinct Scottish immigration policy) during the course of negotiations. In the view of the former SNP Cabinet Secretary, Alex Neil, the Scottish Government has been presented with a 'golden opportunity' to lobby for more powers and greater resources on such a scale as to amount to (what he calls) 'neo-independence'; the 'ideal platform', he has said, 'for advancing full sovereignty for the Scottish people in the early 2020s.' ${ }^{48}$ For Jim Gallagher, both independence and the centripetal repatriation of EU powers should be resisted. Instead, Gallagher has argued that the return of policy making to Holyrood in areas such as fisheries and the environment - as well as the potential for the bespoke devolution of international relations, EU affairs or immigration - would give to the devolved institutions 'an international presence and real autonomy' and would require the UK to work constructively with the devolved institutions in those areas through improved mechanisms for inter-governmental relations. ${ }^{49}$

Whatever the end - an independent Scotland or (what Gallagher calls) a different kind of United Kingdom - there are reasons of principle and of practice why we should be cautious in adopting the suggested means (the transfer of further powers) in order to achieve them. The principled objection

\footnotetext{
${ }^{45} \mathrm{~J}$ Gallagher, Britain after Brexit: Toxic referendums and territorial constitutions (11 October 2016) 6 $<$ http://ggcpp.nuff.ox.ac.uk/wp-content/uploads/2016/10/Britain-after-Brexit-Toxic-Referendums-andTerritorial-Constitutions.pdf $>$.

46 Page (n 17) para 9.

${ }^{47}$ The Smith Commission resolved only to assign a portion of VAT to the Scottish Ministers as EU law does not allow differentiated rates to be applied within a member state. Lord Smith of Kelvin, Report of the Smith Commission for further devolution of Powers to the Scottish Parliament (27 November 2014) para 84 $<$ http://webarchive.nationalarchives.gov.uk/20151202171017/http://www.smith-commission.scot/wpcontent/uploads/2014/11/The Smith Commission Report-1.pdf>.

${ }^{48} \mathrm{~A}$ Neil, 'How my party leader Nicola Sturgeon could get 'neo-independence from Brexit - without another referendum' The Telegraph (25 September 2016) < http://www.telegraph.co.uk/news/2016/09/25/how-myparty-leader-nicola-sturgeon-could-get-neo-independence-f/>.

${ }^{49}$ Gallagher 2016 (n 45) 8-9.
} 
stems from the reactive way in which Scottish devolution has emerged and evolved. This is to say that the dynamic which has driven devolution in Scotland has been the reflexive impulse to devolve powers (and then more powers still) from the centre as the antidote to incremental gains by Scottish nationalists. The Kilbrandon Commission, from which came the aborted Scotland Act 1978, was convened in reaction to those calls for home rule which followed Winnie Ewing's Hamilton byelection win for the SNP in 1967. Two decades later we were told (in the now infamous words of George Robertson) that the devolution settlement implemented by the Scotland Act 1998 would 'kill nationalism stone dead.' The Calman Commission, which preceded the Scotland Act 2012 and (what the then Secretary of State for Scotland described as being) 'the largest ever transfer of fiscal powers since the creation of the UK', was itself a reaction to the SNP's election win in 2007, whilst the Smith Commission and the significant devolution given effect by the Scotland Act 2016 are a direct result of the narrower than expected 'no' vote in the independence referendum.

In none of the above cases has the transfer of power scratched the itch of nationalist agitators. Instead attention has turned to those powers that remain out of reach and which might next be forthcoming. In each of these cases that which was missing (consensus amongst the Kilbrandon Commissioners; the SNP and the Conservative Party from the Scottish Constitutional Convention; the SNP again from the Calman Commission; the public from the Smith Commission) has undermined, to a greater or lesser extent, the legitimacy of that which was proposed. With the independence question reignited by divided majorities in Scotland (as well as in Northern Ireland) as compared to England and Wales the real opportunity we have been afforded is not (necessarily) to ask what more can come the way of Holyrood and Victoria Quay in order to stem the tide, but instead to take a step back and to review in a more fundamental, more inclusive and more participatory process the founding principles and the architecture of devolution, as well as the principles which guide the division of competences as between the centre and the devolved institutions.

The practical objection is one of capacity, and this in two senses. First, contrary to those who argued that the new Scottish Parliament would require to do 'precious little'50 by way of law-making the experience from the get go has been of a hyper-active Parliament: an average of 15 ASPs per year stands in stark contrast to the four or five Scottish Acts passed each year in the ten which preceded devolution..$^{51}$ This has required the government to set its (extremely tight) legislative programme 2-3 years in advance of introduction, whilst the ability of MSPs adequately to perform the Parliament's scrutiny function has been hindered both by the sheer volume of legislation, ${ }^{52}$ as well as by the culture of strong party discipline which, it has been said, in a unicameral legislature with a relatively small number of members inhibits 'the independence of mind and the opportunity for detachment

\footnotetext{
$50 \mathrm{~J}$ McCluskie, 'New approaches to UK legislative drafting: the view from Scotland' (2004) 25 Statute Law Review 136, 138-139.

${ }^{51}$ A Page, 'One Legal System, Two Legislatures: Scottish Law-Making After Devolution' in A McHarg and T Mullen (eds), Public Law in Scotland (Avizandum 2006) 11-12.

52 In its $3^{\text {rd }}$ report, The Founding Principles of the Scottish Parliament: the application of Access and Participation, Equal Opportunities, Accountability and Power Sharing in the work of the Parliament (Scottish Parliamentary Paper 818, 2013) the Procedures Committee warned of 'clear evidence that the committee system in the Scottish Parliament is under severe pressure of work, and that the quality of output is threatened' as a result (at para 101).
} 
and genuine self-criticism that is essential to effective scrutiny. ${ }^{\prime 53}$ These assessments were made before the full effects of further devolution in the Scotland Acts 2012 and 2016 have made themselves known, let alone the demands that will be made by the repatriation of powers following Brexit. It seems highly likely that more - and more complex - powers, which will require a greater volume and (in light of the the transfer of significant tax varying and tax creation powers) perhaps even a greater degree of parliamentary scrutiny, will only place further strain on the legislative timetable. Without careful thought about the capacity of the Scottish Parliament the effectiveness of the scrutiny afforded to the government's programme is likely to suffer, to the detriment of Holyrood's legislative output. Secondly, with the shift from a tax spending to a tax raising parliament, the capacity of the Scottish Government and the Scottish Parliament to exercise new (let alone existing) functions is likely to be hampered by Brexit in the medium to long term by producing a shrinking and less affluent tax base.

We should be wary then - as we ought to have been during the rush to the Smith Commission and through that forum to the Scotland Act 2016 - of embracing more devolved powers without also thinking about the structures which surround their exercise and scrutiny. Does the Scottish Parliament need - as the outgoing Presiding Officer, Trisha Marwick, has suggested ${ }^{54}$ - a second chamber to provide the independent and detached scrutiny referred to by Lord Hope? Are more MSPs required within the unicameral chamber in order to create the space within which a strong(er) backbench culture might emerge? Should we reform the committee system in order to create there a more robust forum for scrutiny? What of the legislative procedure: do we need more or different legislative stages (in one chamber or in two) in order to enhance the quality of ASPs which are submitted for Royal Assent? Is the machinery for Inter-Governmental Relations fit for purpose? How might the devolved institutions routinely feed into policy discussions on reserved matters that nevertheless have significant effects on the devolution settlement? Whatever the answers to these questions, and there are many more besides, the point is that the constitutional rupture created by Brexit will require us to reflect upon the radical substantive changes to devolution that have taken place since the Scotland Act 1998 came into force and to think about the structural work that remains to be done within Scotland and between Scotland and the rest of the UK in order best to accommodate them.

\section{Conclusion}

More than three months after the historic decision was taken to leave the EU the meaning and the shape of Brexit remain less than clear. What we can say with some certainty is that the top down imposition of a 'hard' Brexit will be intolerable for those nations which voted to remain in the EU. From Scotland, where the electorate voted to remain in the EU, where the vast majority of the Members of both the Scottish Parliament and of the House of Commons are pro-EU, and where the Scottish Government has provided a principled counterpoint to the Conservative Government's hard line on immigration (with its knock on effect for our prospects in the single market) the threat to the UK is clear. The demand for greater scrutiny by Holyrood even over UK secondary legislation, the

\footnotetext{
${ }^{53}$ Lord Hope, 'What a second chamber can do for legislative scrutiny' (2004) 25 Statute Law Review 3, 8. For a more detailed assessment of the effectiveness of legislative scrutiny in the Scottish Parliament see Page (2015) (n 39) 217-219.

54 'Presiding Officer calls for second chamber for Holyrood' BBC News (9 March 2016) $<$ http://www.bbc.co.uk/news/uk-scotland-scotland-politics-35761663>.
} 
assertion by the Scottish Government of the Scottish Parliament's right to legislate for an independence referendum even in the face of UK reticence, and the demand for greater autonomy even in areas that are traditionally reserved to the UK, such as immigration and foreign affairs, may offend a still pervasive unitary state instinct, but for those politicians and officials who operate at the centre the stakes could not be higher: to adapt once more in the face of a clear democratic deficit, or for the constitution finally to buckle under the strain of its split identity. 